\title{
High Altitude Sites for Astroparticle Observatories in Peru
}

Jose Bellido*

The University of Adelaide, Australia

E-mail: jose.bellidocacereseadelaide.edu.au

\section{Andres Romero-Wolf}

Jet Propulsion Laboratory, California Institute of Technology, USA

E-mail: andrew.romero-wolf@jpl.nasa.gov

Rolando Perca Gonzales, Jose Vega Ramirez

Universidad Nacional de San Agustín de Arequipa, Perú

E-mail: rperca@unsa.edu.pe, jvegareunsa.edu.pe

\section{Sayri Garcia Roca, Marco Zamalloa}

Universidad Nacional San Antonio Abad del Cusco, Perú

E-mail: sayri.garcia@unsaac.edu.pe, marco.zamalloa@unsaac.edu.pe

\section{Jorge Samanes, Luis Otiniano}

Comisión Nacional de Investigación y Desarrollo Aeroespacial del Perú

E-mail: jsamanes@conida.gob.pe, lotiniano@conida.gob.pe

\section{Walter Guevara Day}

Facultad de Ciencias Físicas, Universidad Mayor de San Marcos, Perú

E-mail: wguevarad@unmsm.edu.pe

\section{Fabian Schüssler}

IRFU, CEA, Université Paris-Saclay, F-91191 Gif-sur-Yvette, France

E-mail: fabian.schussler@cea.fr

\section{Samridha Kunwar}

Max-Planck-Institut für Kernphysik, Saupfercheckweg 1, D-69117 Heidelberg, Germany

E-mail: kunwar@mpi-hd.mpg.de

This paper describes four high altitude sites in southern Peru that were visited, in March 2019, by members of the SGSO Alliance (currently the SWGO Collaboration). The sites are located above 4000 m.a.s.l. with access to water resources and are located between 1 to 4 hours drive from the closest airport. Peruvian authorities, local populations and universities offer support and encourage international collaborations to consider these sites for Astroparticle Observatories.

36th International Cosmic Ray Conference -ICRC2019-

July 24th - August 1st, 2019

Madison, WI, U.S.A.

\footnotetext{
* Speaker.
} 


\section{Introduction}

The Southern hemisphere is of particular interest for observations of the galactic region that are not possible to observe from Northern hemisphere Observatories [1, 2], of particular interest is the center of our galaxy. Observations from HESS [3], in the Southern hemisphere, have shown that the galactic plane radiates in the $\mathrm{TeV}$ range, possibly indicating the interaction of cosmic rays with galactic gas. Furthermore, numerous galactic $\mathrm{TeV}$ sources and some $\mathrm{PeV}$ candidate sources have been observed, which makes it interesting to improve the sensitivity an resolution of next generation gamma-ray Observatories.

The HESS observations are based on the Imaging Atmospheric Cherenkov Technique (IACT) [4], which perform observation only during night time. An alternative $\mathrm{TeV}$ detection method is using a dense array of ground particle detectors. This technique has been successfully use by the HAWC collaboration, that operates a dense ground array in Sierra Negra in Mexico [2]. The angular resolution of ground arrays is not as good as using Cherenkov Telescopes. However, it operates continuously and have a much wider field of view, been it ideal for studies of transients in the $\mathrm{TeV}$ range.

The next generation of gamma-ray Observatories will need to increase its angular resolution and extend the energy range to lower and higher energies. In order to extend the sensitivity to higher energies, the Observatory has to cover a larger area, and to extend to lower energies the Cherenkov telescopes or particle detector modules have to be larger. For the case of ground particle detectors, it is also necessary to place the Observatory higher in altitude.

The next generation of Cherenkov telescopes will be build in Chile by the CTA collaboration [5], and currently there is a search for sites for the next generation $\mathrm{TeV}$ ground array Observatory, the "Southern Wide field-of-view Gamma-ray Observatory" (SWGO) [6]. So, we present in this paper a range of possibilities for a high altitude $\mathrm{TeV}$ ground array Observatory. We have considered the possibility of deploying the ground array inside a high altitude lake. So, a lake in Peru that is located at 4900 m.a.s.l. is included in this paper.

\section{Peruvian high altitude sites}

The Andes mountains traverse South America from North to South offering a range of high altitude sites for Astronomy and Astrophysics Observatories. We have explored sites from Southern Peru and present here four sites that have access to water sources and access road.

Figure 1 shows the location of the four high altitude sites, Sibinacocha Lake in the Cusco region, Sumbay and Imata in the Arequipa region, and the site for the Peruvian National Observatory in the Moquegua region.

The sites of Sumbay and Imata are connected with the Matarani Port via a train line. This is convenient for transporting international shipping of equipment from the Matarani Port. The city of Sicuani, which is 2.5 hours driving to Sibinacocha lake, is also connected with the Matarani Port via train line. 


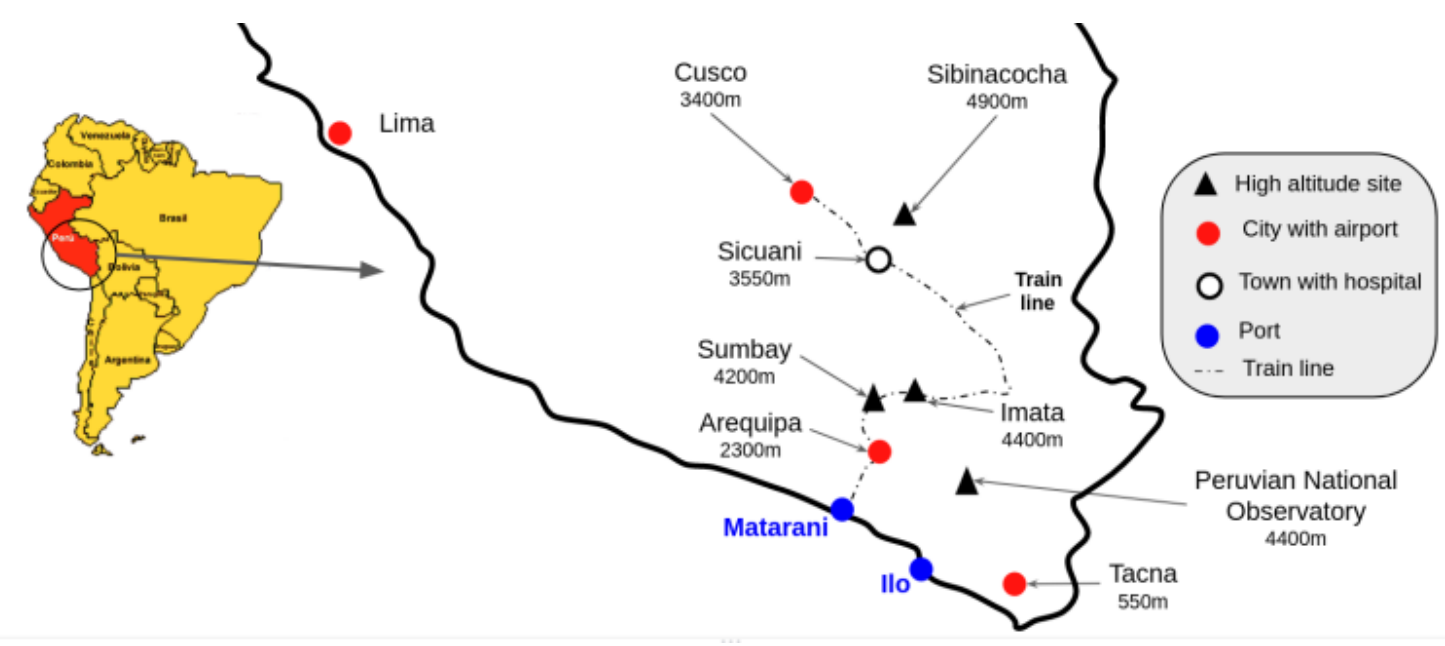

Figure 1: The left hand side map shows the location of Peru in South America and the map on the right shows the southern Peru indicating the location of the four high altitude sites presented in this paper. The map also shows the nearest cities with airport or with a hospital. The sites of Sumbay and Imata are right next to a train line that connect them with the Matarani port. Also the city of Sicuani (close to Sibinacocha lake) is connected with the Matarani port via train line.

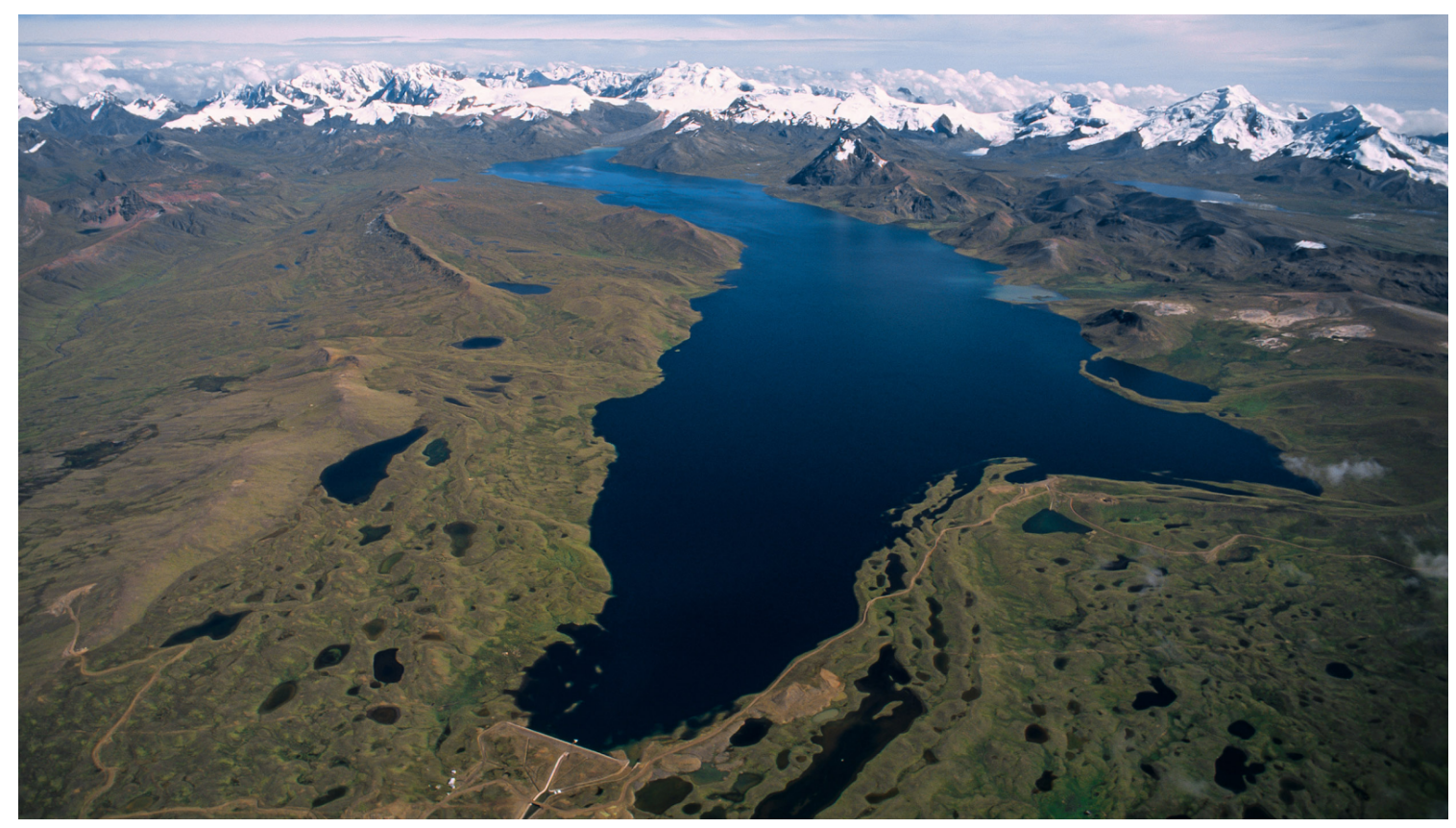

Figure 2: Aerial view of Sibinacocha lake. 


\subsection{Sibinacocha Lake}

The Sibinacocha Lake is located in the Cusco Region, Canchis Province, Pitumarca District. The lake is situated at a height of approximately 4,900 metres, about $15.19 \mathrm{~km}$ long and $2.86 \mathrm{~km}$ at its widest point.

Cusco is the most tourist city in Peru. There are frequent flights between Lima and Cusco (almost every hour) and the flight takes about one hour. Cusco is located at an altitude of 3400 m.a.s.l. There are many alternatives for accommodation and for organizing conferences.

There are two access roads to Sibinacocha lake, one via Pitumarca and the other via Sicuani as seen in Figure 3(a). Both are about $80 \mathrm{~km}$ long of unpaved road, but because of the characteristics of the road, the road via Sicuani is faster, it is about 2 to 2.5 hours driving, compared to 3 hours via Pitumarca road.

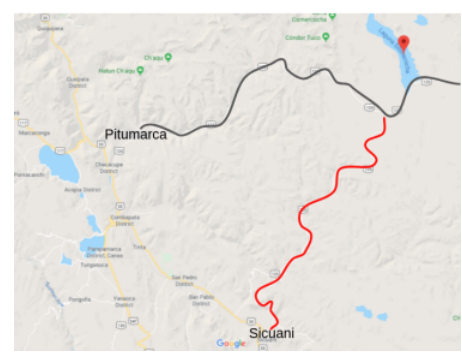

(a) Access to Sibinacocha

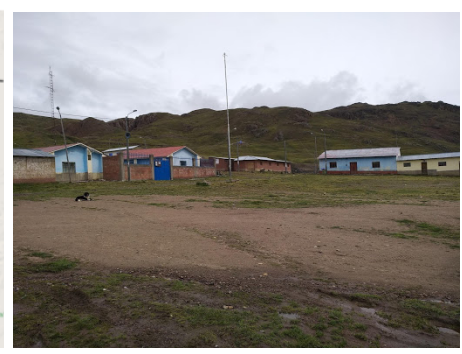

(b) Phinaya village

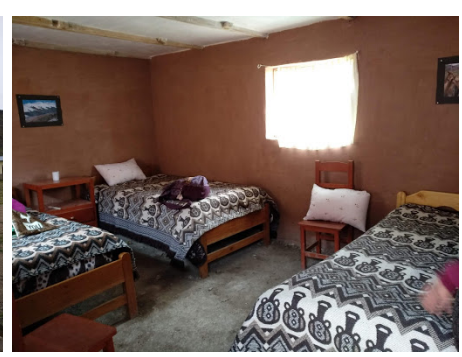

(c) Accommodation

Figure 3: (a) There are two access road to Sibinacocha Lake, one via Pitumarca and the other via Sicuani. (b) The small town of Phinaya is only 10 minutes driving from the Sibinacocha Lake. (c) There is a tourist accommodation in Phinaya.

The city of Cusco that has an airport connecting with the capital city, Lima, is about 1 hour driving to Pitumarca and about 2 hours driving to the city of Sicuani. The Pitumarca road is also used by tourists visiting the Rainbow Mountain [7] and the approval process for the project of paving the road is in a very advance stage.

There is a small town 10 minutes driving from Sibinacocha lake, this is the town of Phinaya. It has a nursery and a tourist accommodation that can host up to about 15 people. The town is an excellent source for local labour.

\subsection{Sumbay and Imata}

The sites of Sumbay (at 4200 m.a.s.1.) and Imata (at 4400 m.a.s.l) are located in the region of Arequipa. Figure 4 shows the location of both sites.

Arequipa is the second city of Peru. There are frequent flights between Lima and Arequipa (almost every hour) and the flight takes a bit more than an hour. Arequipa is conveniently located at an altitude of 2300 m.a.s.l, which is ideal to start getting used to high altitude sites.

The Sumbay site is property of the local University, (Universidad Nacional San Agustin de Arequipa [10]) and it is located next to the river Sumbay. It takes about 1.5 hours drive from Arequipa over a paved road in excellent conditions. 
The Imata site is located next to the Imata town, which is used as a stopping point for truck drivers. This site has two lakes and large flat areas that can also be used to extend the ground array. It also takes about 1.5 hours drive from Arequipa over a paved road in excellent conditions. The squares drawn inside the Imata lakes in figure 4 indicate the size of $500 \mathrm{~m} \times 500 \mathrm{~m}$, which is the proposed size for the SWGO ground array.

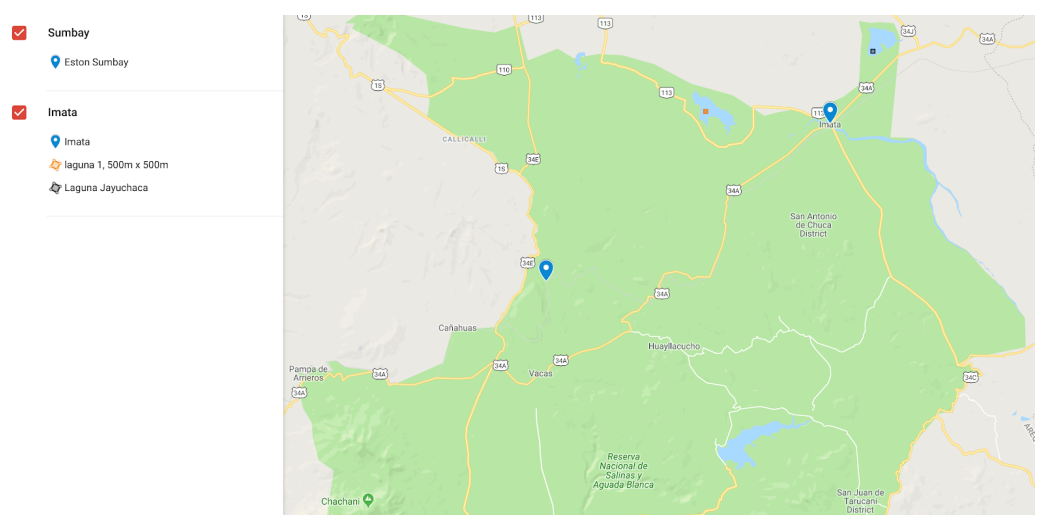

Figure 4: Map showing the sites of Sumbay and Imata. There are two lakes available in Imata. The small squares drawn in the Imata lakes show the dimensions of $500 \mathrm{~m} \times 500 \mathrm{~m}$.

\subsection{Peruvian National Observatory}

This is the southernmost site, it is located in the region of Moquegua at an altitude 4400 m.a.s.l.. The site is next to a paved road in excellent conditions. The nearest airport is in the city of Tacna. There is only two or three flights during the day between Lima and Tacna.

The port of Ilo is about 3 hours driving to the site. At the site there is currently some infrastructure for accommodation.

This site is under the administration of CONIDA [8], the Peruvian Space Agency, and the agency is planning to build here the national facilities for Astronomical observations.

\section{Support from Peruvian authorities, local populations and institutions}

There is high interest from local an national authorities to attract international scientific projects to be based in Peru. The governor of the Arequipa region offered public land for the use of the SWGO collaboration (Fig. 5(a)). The CONCYTEC (Consejo Nacional de Ciencia y Tecnologia) [9] offered their support to intermediate with government officials, Research Institutions and Universities (Fig. 5(b)).

In Arequipa, the local university (Universidad Nacional de San Agustin) offered to provide basic infrastructure if SWGO chooses the site of Sumbay. The site of Sumbay is property of the University. Basic infrastructure means, electricity, internet and good access road (there are $2 \mathrm{~km}$ of road, between main road and the Sumbay site, that needs work). Similar deals could be achieved with National and local governments if a different site in Peru is chosen.

In Southern Peru, in the regions of Arequipa, Cusco and Moquegua, there are important mining companies. Mining companies pay special taxes that goes to local governments and local 


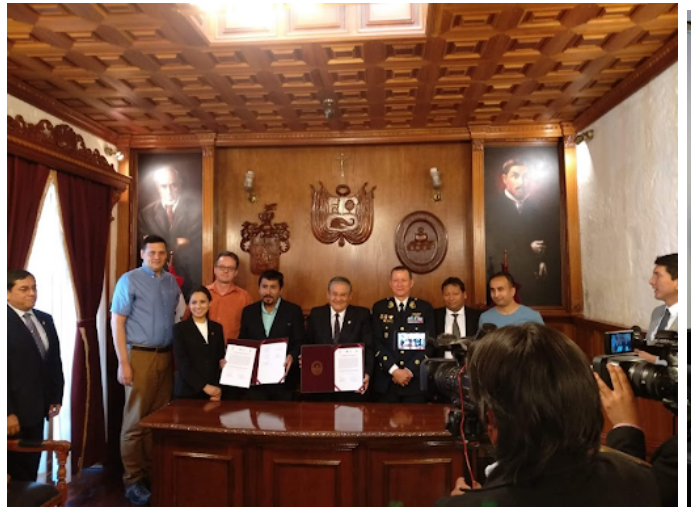

(a) Meeting at the University in Arequipa

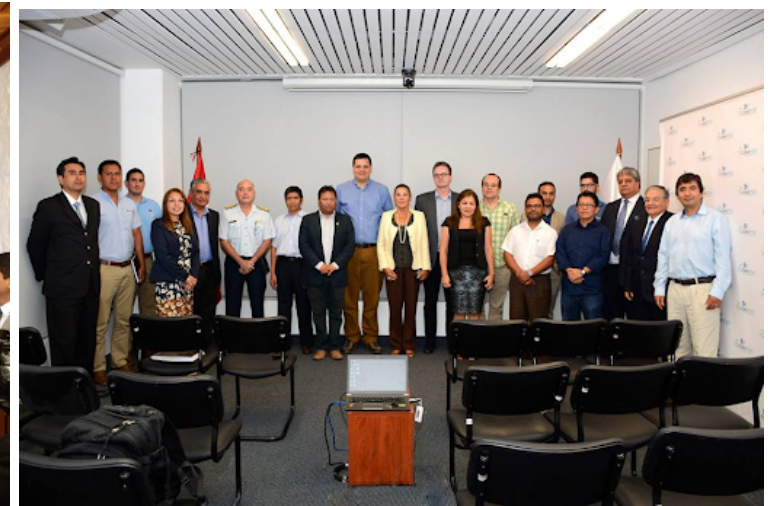

(b) Meeting at CONCYTEC

Figure 5: (a) Meeting at the University of Arequipa [10], where the University and local authorities invited the SWGO collaboration to establish in Arequipa. (b) Meeting at CONCYTEC: President of CONCYTEC [9], Director of the Peruvian Space Agency [8], President of the science and technology commission of the Congress and scientist from main universities in Lima.

universities. Universities can only spend the money from mining taxes in scientific research. The University of Arequipa distributes the mining tax in a series of funding schemes [11]. For example, in basic science one could apply up to S/250k Peruvian soles (US\$76k) per project to be spend in 1.5 to 2 years [12]. These are standard funding programs, but the University is able to fund special projects, for example the University is currently funding a multi-million dollars project to study the sustainability of the water resources, co-existence of agricultural and mining activities [13].

The "Alcalde" of the district of Pitumarca, which is the district where the Sibinacocha lake is located, also offered complete support for installing particle detectors at the Sibinacocha Lake. The "Alcalde" informed the locals about the SWGO project and they welcomed this possibility (Fig. 6).

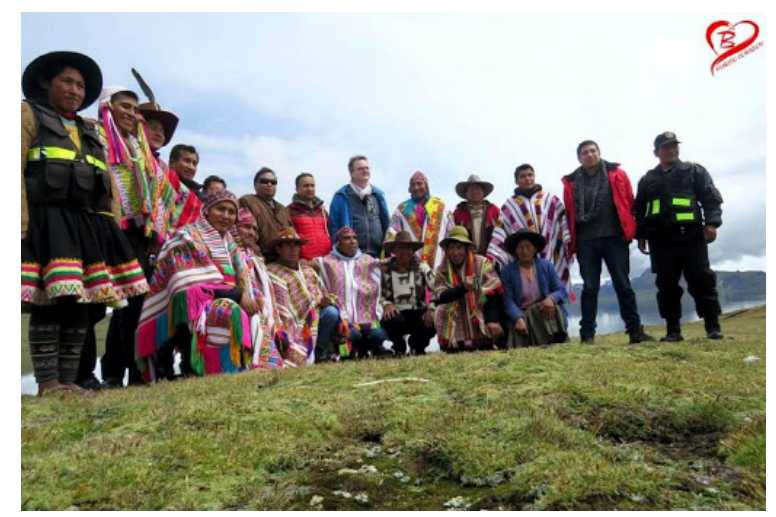

Figure 6: Inhabitants of the Sibinacocha region welcomed the possibility of installing SWGO detectors at the Sibinacocha lake. The picture was taken next to the Sibinacocha lake with local authorities and community leaders. 


\section{Conclusion}

Peru offers a range of possibilities for high altitude sites and there are possibilities for funding from the mining tax.

Below is a summary of the Peruvian sites that were visited by members of the SGSO Alliance, a community of scientists that has recently been given rise to the SWGO collaboration [6].

Table 1: Information Summary.

\begin{tabular}{c|c|c|c|c|c}
\hline Site & $\begin{array}{c}\text { Altitude } \\
\text { m.a.s.l. }\end{array}$ & $\begin{array}{c}\text { Latitude } \\
\text { (degrees) }\end{array}$ & $\begin{array}{c}\text { Driving to } \\
\text { nearest town }\end{array}$ & $\begin{array}{c}\text { Driving to } \\
\text { nearest airport }\end{array}$ & $\begin{array}{c}\text { Conditions of } \\
\text { access road }\end{array}$ \\
\hline $\begin{array}{c}\text { Peruvian } \\
\text { National Observatory }\end{array}$ & 4400 & -17 & 3 hours & 4 hour & paved \\
\hline $\begin{array}{c}\text { Sibinacocha Lake } \\
\text { Sibata (lake and large }\end{array}$ & 4900 & -13 & 2.5 hours & 4.5 hour & $\begin{array}{c}\text { Paved Cusco/Sicuani (2 hours) } \\
\text { flat areas are available) }\end{array}$ \\
\hline Sumbay & 4200 & -16 & 1.5 hours & 1 hour & paved Sicuani/Sibinacocha (2.5 hours) \\
\hline
\end{tabular}

\section{References}

[1] http://www.magic.iac.es

[2] https://www.hawc-observatory.org

[3] H.E.S.S Collaboration, “The H.E.S.S. Galactic plane survey”, A\&A Volume 612, April 2018.

[4] Weekes, Trevor C., "The Atmospheric Cherenkov Technique in Very High Energy Gamma-Ray Astronomy”, Space Science Reviews, Volume 75, Issue 1-2, pp. 1-15, (1996)

[5] https://www.cta-observatory.org

[6] https://www.swgo.org/SWGOWiki/doku.php

[7] https://www.flashpackerconnect.com/region/rainbow-mountain

[8] http://www.conida.gob.pe

[9] https://portal.concytec.gob.pe/

[10] https://www.unsa.edu.pe

[11] http://vri.unsa.edu.pe

[12] http://vri.unsa.edu.pe/proyectos-de-investigacion-basica-o-aplicada-en-ingenierias-o-biomedicas2019-1

[13] http://www.unsa.edu.pe/la-unsa-y-purdue-university-ee-uu-presentan-reporte-anual-de-avance-eninvestigaciones-en-ciencias-de-la-sostenibilidad 